\title{
Detection of Transgenic and Endogenous Plant DNA in Rumen Fluid, Duodenal Digesta, Milk, Blood, and Feces of Lactating Dairy Cows
}

\author{
R. H. Phipps, ${ }^{*}$ E. R. Deaville, $†$, and B. C. Maddison $†$ \\ *Centre for Dairy Research, School of Agriculture, Policy and Development, \\ The University of Reading RG6 6AR, U.K. \\ †ADAS Nutritional Sciences Research Unit, Stratford-on-Avon CV37 9RQ, U.K.
}

\section{ABSTRACT}

The objective was to determine the presence or absence of transgenic and endogenous plant DNA in ruminal fluid, duodenal digesta, milk, blood, and feces, and if found, to determine fragment size. Six multiparous lactating Holstein cows fitted with ruminal and duodenal cannulas received a total mixed ration. There were two treatments $(\mathrm{T})$. In $\mathrm{T} 1$, the concentrate contained genetically modified (GM) soybean meal (cp4epsps gene) and GM corn grain (cry1a[b] gene), whereas T2 contained the near isogenic non-GM counterparts. Polymerase chain reaction analysis was used to determine the presence or absence of DNA sequences. Primers were selected to amplify small fragments from singlecopy genes (soy lectin and corn high-mobility protein and cp4epsps and cry1a[b] genes from the GM crops) and multicopy genes (bovine mitochondrial cytochrome $\mathrm{b}$ and rubisco). Single-copy genes were only detected in the solid phase of rumen and duodenal digesta. In contrast, fragments of the rubisco gene were detected in the majority of samples analyzed in both the liquid and solid phases of ruminal and duodenal digesta, milk, and feces, but rarely in blood. The size of the rubisco gene fragments detected decreased from $1176 \mathrm{bp}$ in ruminal and duodenal digesta to $351 \mathrm{bp}$ in fecal samples.

(Key words: DNA detection, digesta, GM feeds, milk)

Abbreviation key: GM = genetically modified, HMP $=$ maize high-mobility protein, $\mathbf{L O D}=$ limit of detection, $\boldsymbol{r b c L}=$ rubisco, $\mathbf{S L}=$ soy lectin, $\mathbf{t D N A}=$ transgenic DNA, $\mathbf{T}=$ treatment.

\section{INTRODUCTION}

In 2002, 59 million ha of genetically modified (GM) crops were grown globally (James, 2002). The principal

Received June 4, 2003.

Accepted August 18, 2003.

Corresponding author: R. H. Phipps; e-mail r.h.phipps@ reading.ac.uk. crops are soybeans, corn, cotton, and rapeseed, which have been modified for agronomic traits such as herbicide tolerance and/or insect protection. These crops are all used in diets for productive livestock and may be included either in the form of a whole crop (e.g., maize silage), a specific crop component (e.g., corn grain), or as coproducts (e.g., oilseed meals).

Concern has been expressed about the use of GM crops in animal feeds. One issue raised is whether transgenic DNA (tDNA) could be transferred to and accumulate in milk, meat, or eggs. A number of studies have now been conducted in which tDNA has not been detected in these food products derived from livestock receiving GM feed ingredients (Ash et al., 2000; Weber and Richert, 2001; Phipps et al., 2002; Jennings et al., 2003a, 2003b). However, small fragments (199 bp) of plant chloroplast DNA have been detected in some animal tissues (Einspanier et al., 2001; Klotz et al., 2002; Reuter and Aulrich, 2003).

These studies have focused primarily on the presence or absence of tDNA in foods derived from animals receiving GM feed ingredients, but none has examined the extent to which tDNA survives in different parts of the ruminant digestive tract. Therefore, the current study aimed at determining the presence or absence of tDNA and endogenous plant DNA in ruminal fluid, duodenal digesta, feces, blood, and milk derived from lactating dairy cows, and if found, to determine DNA fragment size.

\section{MATERIALS AND METHODS}

\section{Cows and Diet Composition}

Six multiparous lactating Holstein-Friesian cows (average $\mathrm{DIM}=61 \mathrm{~d}$, initial live weight $=641 \mathrm{~kg}$, and milk yield $=46.7 \mathrm{~kg} / \mathrm{d}$ ), each with permanent cannulas in the rumen and proximal duodenum, were allocated to the study. The work was conducted under the U.K. Animals (Scientific Procedures) Act of 1986 (http:// www.homeoffice.gov.uk/docs/animallegislation.html) and under the control of staff holding appropriate licenses under the Act. All cows received a TMR containing forage and concentrate in a 55:45 DM ratio. 
Corn and grass silage formed 41.2 and $13.8 \%$ of total dietary DM, whereas ground corn grain, soybean meal, rapeseed meal, and minerals contributed 18.5, 13.0, 12.5 , and $1.0 \%$ of total dietary DM, respectively.

\section{Experimental Treatments and Study Design}

There were two treatments (T1 and T2), each with three cows. In T1, the concentrate portion of the TMR contained GM soybean meal (cp4epsps gene for Monsanto Roundup Ready Soybean event GTS 40-3-2; St. Louis, MO) and ground GM corn grain (cry1a[b] gene for Monsanto YieldGard Bt Maize event MON810), whereas for T2, the concentrate contained the near isogenic non-GM soybean meal and ground non-GM maize grain counterparts. The forage and other dietary components were the same for both treatments. All cows received fresh feed daily and water was freely available. The study design was a single reversal design with three 4-wk periods.

Total mixed rations intended to be GM-free, but some were erroneously made with the GM feed ingredients described above and fed to two animals in two experimental periods during the course of the study. Therefore, the data from these animals were considered as part of the GM treatment group (total $\mathrm{n}=13$ ) and not the non-GM treatment group (total $n=5$ ).

\section{Sampling Procedures}

Duplicate milk samples $(50 \mathrm{ml})$ were taken from each cow on 3 consecutive days (Tuesday to Thursday) during the morning and afternoon milking in wk 1 and 4 of each period. All samples were stored frozen at approximately $-20^{\circ} \mathrm{C}$. Ruminal fluid, duodenal digesta, and feces were sampled and processed for analysis according to the procedures reported by Sutton et al. (2000). Three ruminal, duodenal, and fecal samples were taken at 6 -h intervals on each of the 3 sampling days in wk 4 of each period. Sampling started at 0700 $\mathrm{h}$ on $\mathrm{d} 1$, and $2 \mathrm{~h}$ later on each successive day to provide a series of nine 2-h sampling intervals over the period from 0700 to $2300 \mathrm{~h}$. The nine ruminal, duodenal, and fecal samples were bulked into single samples. The bulked samples were stirred vigorously and subsamples prepared. Ruminal fluid and duodenal digesta were separated into solid and liquid phases by centrifugation of $10 \mathrm{ml}$ at $15,000 \mathrm{rpm}$ for $15 \mathrm{~min}$. The solid phase was stored at $-20^{\circ} \mathrm{C}$ and the liquid phase was freeze-dried prior to grinding in liquid nitrogen. On $1 \mathrm{~d}$ during wk 4 of each period, a total of $15 \mathrm{ml}(5 \mathrm{ml}$ on 3 separate occasions) of peripheral blood was collected from the tail vein of all cows. Composite samples were used to determine the presence or absence of specific DNA se- quences from corn grain and soybean meal, and the presence of transgenic protein.

\section{Extraction of DNA}

All feed, digesta, and fecal samples were finely ground using liquid nitrogen and mortar and pestles. The DNA was extracted ( $25 \mathrm{mg}$ of soybean meal; $100 \mathrm{mg}$ of maize grain, TMR, solid-phase ruminal and duodenal digesta, and feces; $100 \mu \mathrm{l}$ of resuspended liquid-phase ruminal and duodenal digesta) using the cetyl trimethyl ammonium bromide method (MAFF, 1999). The DNA was extracted from bovine whole blood $(400 \mu \mathrm{l})$ using the approach described by Boom et al. (1990). From raw milk (4 ml), DNA was extracted using a cetyl trimethyl ammonium bromide/chloroform method based on a milk DNA extraction protocol from Monsanto Co.

With the exception of milk, the extracted DNA from all samples was resuspended in $100 \mu \mathrm{l}$ of molecular biology-grade water (60 $\mu \mathrm{l}$ for milk). The yield and purity of the extracted DNA (1:50 dilution) were determined following measurement of UV absorption at $\mathrm{A}_{260}$ and $\mathrm{A}_{280}$. All extracted DNA was stored frozen at $-80^{\circ} \mathrm{C}$ until used. During each extraction procedure, an extraction control (duplicate) was also carried out using only the same buffers/reagents (i.e., with no template DNA). These were then included in the PCR assay for each amplicon and used as controls for contamination during each DNA extraction procedure.

\section{Primer Selection and Design}

Primers were selected to amplify small (approximately $200 \mathrm{bp}$ ) fragments of DNA from the single-copy genes coding for the soy lectin (SL) gene and corn highmobility protein (HMP), and the bovine multicopy mitochondrial gene coding for cytochrome b. To amplify DNA fragments from a multicopy chloroplast gene, a sequence alignment of the Zea mays and Glycine max rubisco (rbcL) genes was generated using the Blast sequence alignment facility (http://www.ncbi.nlm.nih.gov/BLAST/). The sequence alignment was then used to design primers that would amplify both corn and soy $r b c L$ gene fragments.

To detect tDNA in GM corn, a primer sequence from Monsanto Co. was used to amplify a 203-bp fragment overlapping the Hsp70 intron (preceeding the cry $1 a[b]$ transgene) and the cry $1 a(b)$ coding region. To detect the soy transgene, a primer set from Wurz and Willmund (1997) was used. The primers span the $35 \mathrm{~S}$ promoter and chloroplast transit peptide that precedes the epsps transgene in Roundup Ready Soy. A list of the primers used in the study is given in Table 1 together with information relating to their base sequences ( $5^{\prime}$ to $\left.3^{\prime}\right)$, target genes, and amplicon size. 
PHIPPS ET AL.

Table 1. Primers used for the detection of single- and multicopy genes.

\begin{tabular}{|c|c|c|c|c|}
\hline Primer name $^{1}$ & Sequence $5^{\prime}-3^{\prime}$ & Target gene & Amplicon size, bp & Reference $^{2}$ \\
\hline ADRUB F1 & ttccaaggtccgcctcac & Maize/soy rubisco & 167 & 1 \\
\hline ADRUB R1 & catcatctttggtaaaatcaagtcc & & & \\
\hline ADLECT F1 & ccacaaacacatgcaggttatc & Soy lectin & 240 & 1 \\
\hline ADLECT R1 & agaccaaagaagcaaccaagag & & & \\
\hline ADHMP F1 & ttgtgtggattgtaggacaagg & Maize HMP & 209 & 1 \\
\hline $\begin{array}{l}\text { ADHMP R1 } \\
\text { MON } 810 \text { F1 } \\
\text { MON } 810 \text { R1 }\end{array}$ & $\begin{array}{l}\text { gctctgaacaaacaacacatgg } \\
\text { ctccctagtgttgaccagtgttac } \\
\text { ctgcgtgagggagagggagatgtc }\end{array}$ & Hsp70-Cry1Ab & 203 & 2 \\
\hline $\begin{array}{l}\text { 35S-CTP F1 } \\
\text { 35S-CTP R1 }\end{array}$ & $\begin{array}{l}\text { cgatgtgatatctccactgacg } \\
\text { tgtatccettgacccatgttgt }\end{array}$ & 35S-CTP & 171 & 3 \\
\hline $\begin{array}{l}\text { CYTB F1 } \\
\text { CYTB R1 }\end{array}$ & $\begin{array}{l}\text { atcaaccccaaagctgaag } \\
\text { tctgtgtatgggcgtgttatg }\end{array}$ & Bovine Cyt B & 183 & 1 \\
\hline $\begin{array}{l}\text { RUB F2 } \\
\text { RUB R2 }\end{array}$ & $\begin{array}{l}\text { ttggcagcattccgagtaac } \\
\text { gtgaggcggaccttggaaag }\end{array}$ & Maize/soy rubisco & 351 & 1 \\
\hline RUB F3 & ggtggacttgattttaccaaagatg & Maize/soy rubisco & $850^{3}$ & 1 \\
\hline RUB F4 & ttaccagtcttgatcgttacaaagg & Maize/soy rubisco & $1176^{3}$ & 1 \\
\hline RUB R4 & gatctccttccatacttcacaagc & & $850^{\#}$ & \\
\hline
\end{tabular}

\footnotetext{
${ }^{1} \mathrm{ADLET}, \mathrm{ADHMP}, \mathrm{RUB}$ = forward and reverse primers used to amplify soy lectin, maize high-mobility protein, and rubisco gene fragments, respectively. 35S-CTP = forward and reverse primers used to amplify a fragment overlapping the 35S promoter and chloroplast transit peptide that precedes the epsps transgene; MON 810 = forward and reverse primers used to amplify a fragment overlapping the Hsp70 intron and the cry $1 a(b)$ coding region; CYTB = forward and reverse primers used to amplify bovine cytochrome B. R1, R2, and $\mathrm{R} 4$ and F1, F2, F3, and F4 = reverse and forward primers, respectively.

${ }^{2} 1$ = milkers, 2 = Monsanto Co. (St. Louis, MO), 3 = Wurz and Willmund (1997).

${ }^{3}$ With RUB R4.

${ }^{4}$ With RUB F3.
}

\section{Polymerase Chain Reaction Methodologies}

The amount of total DNA added to each PCR reaction $(5 \mu \mathrm{l})$ was $100 \mathrm{ng}$ for the feed, digesta, and fecal samples, and $400 \mathrm{ng}$ for blood. For milk, $5 \mu \mathrm{l}$ of the isolated, resuspended DNA was added (i.e., each PCR reaction contained the DNA in $333 \mu \mathrm{l}$ of the raw milk samples). The optimal amount of DNA added to each PCR reaction was obtained through PCR analysis using a set amount of target DNA (corn/soy) added to an increasing amount of sample DNA collected from animals consuming nonGM diets (data not presented). The PCR was carried out in a final volume of $30 \mu \mathrm{l}$ of $1 \times$ PCR buffer containing $200 \mu M$ dNTP mix (Abgene), $1 \mu M$ each primer, $2 \mathrm{~m} M$ magnesium chloride, and 0.75 units "Red Hot" DNA polymerase (Abgene). The PCR was carried out using a GeneAmp PCR System 9700 (Applied Biosystems, Warrington, U.K.) and the following temperature profile: initial denaturation at $94^{\circ} \mathrm{C}$ for $5 \mathrm{~min}$, annealing/extension at $62^{\circ} \mathrm{C}$ for $10 \mathrm{~s}$, denaturation at $94^{\circ} \mathrm{C}$ for $20 \mathrm{~s}$, and soaking at $72^{\circ} \mathrm{C}$ for $5 \mathrm{~min}$. All PCR reactions were "hot started" by placing the PCR plates on the preheated $\left(94^{\circ} \mathrm{C}\right) \mathrm{PCR}$ machine. A total of 35 PCR cycles was completed for the feed samples, whereas for all other samples, 40 cycles were carried out. When assembling each PCR plate, a positive control (5 ng of a GM corn/soya standard), negative control ( $5 \mu \mathrm{l}$ of water), and an extraction control for the sample DNA to be amplified were routinely set up. Each nonfeed DNA sample was also tested for bovine cytochrome b. If a PCR product was not obtained after 40 cycles, then DNA was reextracted from the original sample.

The limit of detection (LOD) of each amplicon in each sample type was determined using LOD assays. A titration of GM corn/soy DNA was spiked into each type of sample DNA, PCR was carried out for each amplicon, and the lowest amount of target DNA detectable within a particular sample DNA was called the LOD. This was carried out to better understand the matrix effects of each sample DNA caused by impurities that copurify with each DNA type. Milk samples were spiked with extracted GM DNA, and then the DNA was extracted and PCR was carried out. The LOD of each amplicon/ DNA type are shown in Table 2. This information, is provided to qualify any negative PCR results.

\section{Agarose Gel Electrophoresis}

The extracted DNA (10 $\mu \mathrm{l})$ from the soybean meal and corn samples and the PCR products were separated using $0.8 \%$ (wt/vol) and $2 \%$ agarose gels, respectively, containing $1 \mu \mathrm{g} / \mathrm{ml}$ of ethidium bromide. Electrophoresis was carried out at approximately $100 \mathrm{~V}$ for 1.5 to 2 $\mathrm{h}$, and the DNA was then visualized under UV light.

\section{Sequencing}

To validate the positive PCR results, PCR products from the amplified feed material and 2 milk samples 
Table 2. Limit of detection for each of the amplicons in each sample type.

\begin{tabular}{llllll}
\hline \multirow{2}{*}{$\begin{array}{l}\text { Background } \\
\text { material }\end{array}$} & \multicolumn{5}{c}{ Amplicon } \\
\cline { 2 - 5 } & Rubisco & $\mathrm{SL}$ & $\mathrm{HMP}$ & MON 810 & 35 S-CTP \\
\hline Ruminal solid & $\mathrm{Bg}$ & $\mathrm{Bg}$ & $\mathrm{Bg}$ & $500 \mathrm{pg}$ & $500 \mathrm{pg}$ \\
Ruminal liquid & $\mathrm{Bg}$ & $5 \mathrm{ng}$ & $5 \mathrm{ng}$ & $500 \mathrm{pg}$ & $50 \mathrm{ng}$ \\
Duodenal solid & $\mathrm{Bg}$ & $\mathrm{Bg}$ & $\mathrm{Bg}$ & $500 \mathrm{pg}$ & $50 \mathrm{pg}$ \\
Duodenal liquid & $\mathrm{Bg}$ & $5 \mathrm{ng}$ & $5 \mathrm{ng}$ & $500 \mathrm{pg}$ & $50 \mathrm{ng}$ \\
Feces & $\mathrm{Bg}$ & $5 \mathrm{ng}$ & $500 \mathrm{pg}$ & $50 \mathrm{pg}$ & $500 \mathrm{pg}$ \\
Whole blood & $<5 \mathrm{pg}$ & $500 \mathrm{pg}$ & $500 \mathrm{pg}$ & $50 \mathrm{pg}$ & $500 \mathrm{pg}$ \\
Milk & $\mathrm{Bg}$ & $25 \mathrm{ng}$ & $5 \mathrm{ng}$ & $5 \mathrm{ng}$ & $5 \mathrm{ng}$ \\
\hline
\end{tabular}

${ }^{1} \mathrm{SL}=$ soya lectin; HMP = maize high-mobility protein; $\mathrm{Bg}=$ detectable in the background level of DNA without any additional spiked DNA into the sample; 35SCTP = forward and reverse primers used to amplify a fragment overlapping the 35S promoter and chloroplast transit peptide that precedes the epsps transgene, MON 810 = forward and reverse primers used to amplify a fragment overlapping the Hsp70 intron and the cry $1 a(b)$ coding region.

were gel purified using a mini Elute kit (Qiagen Genomic Services, Hilden, Germany) and then sequenced (Qiagen Genomic Services). Sequence data was then pasted into the Blast search facility to match the PCR sequence within the database.

\section{Statistical Analysis}

The results of the study are expressed as positive, negative, or inconclusive PCR results. In every PCR run, the results of the PCR plate were only accepted when the positive control was positive and the negative control and extraction controls were negative for the specific amplicon. A true positive was then recorded only when the correctly sized PCR product was visualized on the ethidium bromide-stained gel for the duplicate PCR runs. No further statistical analysis was completed.

\section{RESULTS AND DISCUSSION}

\section{Feed Analyses}

The chemical composition and nutritional value, determined according to the methods described by Deaville et al. (1994), of the two treatment diets offered throughout the study were similar. The mean concentrations (\% DM) of the $\mathrm{CP}$, starch, $\mathrm{ADF}, \mathrm{NDF}$, oil, and predicted metabolizable energy $(\mathrm{MJ} / \mathrm{kg} \mathrm{DM})$ were 20.0 and $20.1 \%, 29.0$ and $27.5 \%, 17.3$ and $17.5 \%, 29.8$ and $30.5 \%, 3.5$ and $3.3 \%$, and 11.9 and $11.8 \mathrm{MJ} / \mathrm{kg}$ of DM for $\mathrm{T} 1$ and $\mathrm{T} 2$, respectively.

\section{DNA Detection}

GM constructs and near-isogenic counterparts. The results of the PCR analysis of composite soybean and corn grain samples confirmed the presence of the constructs cp4epsps and cry1a(b) in the GM soybean meal and maize grain samples, respectively, and were not detected in the non-GM near isogenic counterparts (gel electrophoresis data are not shown). These results confirmed the correct provenance of the samples. The DNA purified from both the GM and non-GM maize grain was present in fragments greater than $23 \mathrm{~kb}$. This is the expected size of plant genomic DNA that has not undergone any processing except for the laboratory DNA extraction procedure (Smith et al., 2000). In contrast, the DNA in the soybean meal samples was visible on the agarose gel as a smear of degraded DNA fragments from $2 \mathrm{~kb}$ to less than $500 \mathrm{bp}$, indicating DNA fragmentation during industrial processing. This observation is in agreement with Chiter et al. (2000), who reported on the fragmentation of feed DNA during experimental-scale processing. Reporting on the extent of DNA fragmentation in 2 samples of soybean meal, Smith et al. (2000) showed that 1 sample contained intact DNA, whereas the other contained degraded DNA as observed for the present sample of soybean meal.

The results of the PCR analysis also showed that the single-copy SL and HMP genes were only detected in the soybean meal and maize grain samples, respectively, and that the multicopy rubisco gene was detected in all feed samples.

Rumen fluid and duodenal digesta. The presence or absence of feed-derived DNA in the solid and liquid phases of ruminal and duodenal digesta of lactating dairy cows has not been previously documented. Table 3 presents the number of positive, negative, and inconclusive PCR results for each of the amplicons in each digesta sample. The DNA fragments from the singlecopy SL and HMP genes were detected in the majority of solid-phase ruminal and duodenal samples obtained from cows in both treatment groups, whereas the transgenes, cry $1 a(b)$ and cp4epsps, were only detected in samples obtained from cows offered the GM diet. 
Table 3. Detection of positive (+), negative (-), and inconclusive (I) PCR results for each of the amplicons in digesta samples from animals receiving a TMR containing either genetically modified (GM) or conventional (non-GM) feed ingredients.

\begin{tabular}{|c|c|c|c|c|c|c|}
\hline \multirow[b]{2}{*}{ Amplicon $^{1}$} & \multicolumn{3}{|c|}{ GM TMR } & \multicolumn{3}{|c|}{ Non-GM TMR } \\
\hline & + & - & I & + & - & I \\
\hline \multicolumn{7}{|c|}{ Ruminal fluid (liquid phase) } \\
\hline Rubisco & 11 & 0 & 2 & 5 & 0 & 0 \\
\hline MON 810 & 0 & 13 & 0 & 0 & 5 & 0 \\
\hline 35S-CTP & 0 & 13 & 0 & 0 & 5 & 0 \\
\hline SL & 0 & 13 & 0 & 0 & 5 & 0 \\
\hline HMP & 0 & 13 & 0 & 0 & 5 & 0 \\
\hline \multicolumn{7}{|c|}{ Ruminal fluid (solid phase) } \\
\hline Rubisco & 13 & 0 & 0 & 5 & 0 & 0 \\
\hline MON 810 & 5 & 5 & 3 & 0 & 5 & 0 \\
\hline 35S-CTP & 12 & 1 & 0 & 0 & 5 & 0 \\
\hline SL & 13 & 0 & 0 & 5 & 0 & 0 \\
\hline HMP & 7 & 1 & 5 & 1 & 1 & 3 \\
\hline \multicolumn{7}{|c|}{ Duodenal digesta (liquid phase) } \\
\hline Rubisco & 6 & 2 & 5 & 4 & 0 & 1 \\
\hline MON 810 & 0 & 13 & 0 & 0 & 5 & 0 \\
\hline 35S-CTP & 0 & 13 & 0 & 0 & 5 & 0 \\
\hline SL & 0 & 13 & 0 & 0 & 5 & 0 \\
\hline HMP & 0 & 13 & 0 & 0 & 5 & 0 \\
\hline \multicolumn{7}{|c|}{ Duodenal digesta (solid phase) } \\
\hline Rubisco & 13 & 0 & 0 & 5 & 0 & 0 \\
\hline MON 810 & 8 & 5 & 0 & 0 & 5 & 0 \\
\hline 35S-CTP & 11 & 0 & 2 & 0 & 5 & 0 \\
\hline SL & 13 & 0 & 0 & 5 & 0 & 0 \\
\hline HMP & 12 & 1 & 0 & 4 & 0 & 1 \\
\hline \multicolumn{7}{|l|}{ Feces } \\
\hline Rubisco & 12 & 0 & 1 & 5 & 0 & 0 \\
\hline MON 810 & 0 & 13 & 0 & 0 & 5 & 0 \\
\hline 35S-CTP & 0 & 13 & 0 & 0 & 5 & 0 \\
\hline SL & 0 & 13 & 0 & 0 & 5 & 0 \\
\hline HMP & 0 & 13 & 0 & 0 & 5 & 0 \\
\hline
\end{tabular}

${ }^{1} \mathrm{SL}=$ soya lectin; HMP = maize high-mobility protein; 35S-CTP $=$ forward and reverse primers used to amplify a fragment overlapping the $35 \mathrm{~S}$ promoter and chloroplast transit peptide that precedes the epsps transgene; MON 810 = forward and reverse primers used to amplify a fragment overlapping the Hsp70 intron and the cry $1 a(b)$ coding region.

This strongly suggests that the complex feed matrix is not completely digested up to the duodenum. In contrast, no DNA fragments from single-copy genes were detected in the liquid-phase samples. This may reflect the extremely rapid degradation of DNA in these environments, as previously shown by in vitro incubation of naked DNA in rumen fluid (Duggan et al., 2000).

Rubisco DNA fragments were, however, detected in the majority of both ruminal and duodenal solid- and liquid-phase digesta (Table 3). This suggests that sufficient DNA must survive degradation in these fractions in order to be detected by PCR. Although no comparable information could be found in the literature for the solid and liquid phases of ruminal and duodenal digesta, Einspanier et al. (2001) detected small fragments of rubisco DNA in the chyme, a solid/liquid duodenal digesta sample, from cows.

Feces. The DNA fragments of the single-copy genes, SL and HMP, and the transgenes, cry1a(b) and cp4epsps, were not detected in fecal samples (Table 3), suggesting that the digestive tract extensively degrades feed DNA. The abundant chloroplast rubisco gene was, however, detected in fecal samples (Table 3), and is likely to reflect the greater number of copies of the rubisco gene (approximately 10,000 copies per plant cell). These results contrast with the findings of Einspanier et al. (2001), who did not detect rubisco DNA fragments in feces. The detection of any plant DNA in feces is likely to be affected by a number of factors, including the form of the diet fed (e.g., whole grain vs. processed feed) and differences in the LOD determined for various amplicons.

Blood. Table 4 presents the number of positive, negative, and inconclusive PCR results for each of the amplicons in each of the whole blood samples. No single-copy genes including transgenes were detected in any of the samples. This result, together with the detection of fragments of the multicopy rubisco gene in a small number of samples, confirms earlier results reported by Einspanier et al. (2001). 
Table 4. Detection of positive (+), negative (-), and inconclusive (I) results for each of the amplicons in bovine whole blood samples from animals receiving a TMR containing either genetically modified (GM) or conventional (non-GM) feed ingredients.

\begin{tabular}{|c|c|c|c|c|c|c|}
\hline \multirow[b]{2}{*}{ Amplicon $^{1}$} & \multicolumn{3}{|c|}{ GM TMR } & \multicolumn{3}{|c|}{ Non-GM TMR } \\
\hline & + & - & I & + & - & I \\
\hline Rubisco & 1 & 12 & 0 & 2 & 3 & 0 \\
\hline MON 810 & 0 & 13 & 0 & 0 & 5 & 0 \\
\hline 35S-CTP & 0 & 13 & 0 & 0 & 5 & 0 \\
\hline SL & 0 & 13 & 0 & 0 & 5 & 0 \\
\hline HMP & 0 & 13 & 0 & 0 & 5 & 0 \\
\hline
\end{tabular}

${ }^{1} \mathrm{SL}=$ soya lectin; HMP = maize high-mobility protein; 35S-CTP $=$ forward and reverse primers used to amplify a fragment overlapping the $35 \mathrm{~S}$ promoter and chloroplast transit peptide that precedes the epsps transgene; MON 810 = forward and reverse primers used to amplify a fragment overlapping the Hsp70 intron and the cryla(b) coding region.

Milk. Table 5 presents the number of positive, negative, and inconclusive PCR results for each of the amplicons in each of the whole milk samples. No DNA fragments from single-copy genes including transgenes were detected. These results agree with earlier studies, which reported that tDNA could not be detected in milk (Klotz and Einspanier, 1998; Faust, 2000; Einspanier et al., 2001; Phipps and Beever, 2001; Phipps et al., 2002). However, fragments of rubisco DNA (189 bp) were detected in the majority of the milk samples, and this finding agrees with that of Klotz and Einspanier (1998) and Einspanier et al. (2001), who reported the detection of small (199 bp) fragments of the rubisco gene in milk. Further work is needed to determine the mechanisms of molecule transport across the epithelial layer of the gastrointestinal tract into the blood stream.

Rubisco sequencing. Sequencing of the 2 milk samples with a positive PCR signal for the rubisco 189-bp fragment generated a $100 \%$ match to the Zea mays chloroplast $r b c L$ fragment. This result confirmed that the amplification of the rubisco DNA fragment was of dietary origin. It is interesting to note that the rubisco amplicon was designed to amplify both corn and soy- bean meal rubisco fragments. One possible explanation for the result obtained from sequencing the PCR product in milk is that the soybean meal DNA is highly degraded.

Rubisco DNA. The PCR analyses for 351-, 850-, and 1176-bp fragments were conducted in each sample type in which the smaller rubisco fragments (189 bp) had been found. Rubsico DNA fragments of $1176 \mathrm{bp}$ and $850 \mathrm{bp}$ were detected in ruminal fluid and duodenal digesta, but not in fecal samples (Figure 1). Smaller fragments of rubisco DNA of $351 \mathrm{bp}$ could be detected in all types of digesta and feces. The absence of DNA fragments of $1176 \mathrm{bp}$ in fecal samples may be due in part to the diet-derived DNA being degraded in the digestive tract so that only small fragment sizes were present, and or to the lower sensitivity of this PCR amplicon when tested on neat DNA (10 to 100 times less sensitive than for the 351-bp amplicon). These results are at variance with the negative results reported by Einspanier et al. (2001).

Blood samples positive for rubisco were subsequently analyzed for the larger fragment sizes of 351 and 850 bp. In 3 out of 9 samples the 351-bp fragment was

Table 5. Detection of positive (+), negative (-), and inconclusive (I) results for each of the amplicons in bovine milk samples from animals receiving a TMR containing either genetically modified (GM) or conventional (nonGM) feed ingredients.

\begin{tabular}{|c|c|c|c|c|c|c|}
\hline \multirow[b]{2}{*}{ Amplicon ${ }^{1}$} & \multicolumn{3}{|c|}{ GM TMR } & \multicolumn{3}{|c|}{ Non-GM TMR } \\
\hline & + & - & I & + & - & I \\
\hline Rubisco & 57 & 10 & 11 & 26 & 0 & 4 \\
\hline MON 810 & 0 & 78 & 0 & 0 & 30 & 0 \\
\hline 35S-CTP & 0 & 78 & 0 & 0 & 30 & 0 \\
\hline SL & 0 & 78 & 0 & 0 & 30 & 0 \\
\hline HMP & 0 & 78 & 0 & 0 & 30 & 0 \\
\hline
\end{tabular}

${ }^{1} \mathrm{SL}=$ soya lectin; HMP = maize high-mobility protein; $35 \mathrm{~S}-\mathrm{CTP}=$ forward and reverse primers used to amplify a fragment overlapping the $35 \mathrm{~S}$ promoter and chloroplast transit peptide that precedes the epsps transgene; MON 810 = forward and reverse primers used to amplify a fragment overlapping the Hsp70 intron and the $\operatorname{cry} 1 a(b)$ coding region. 

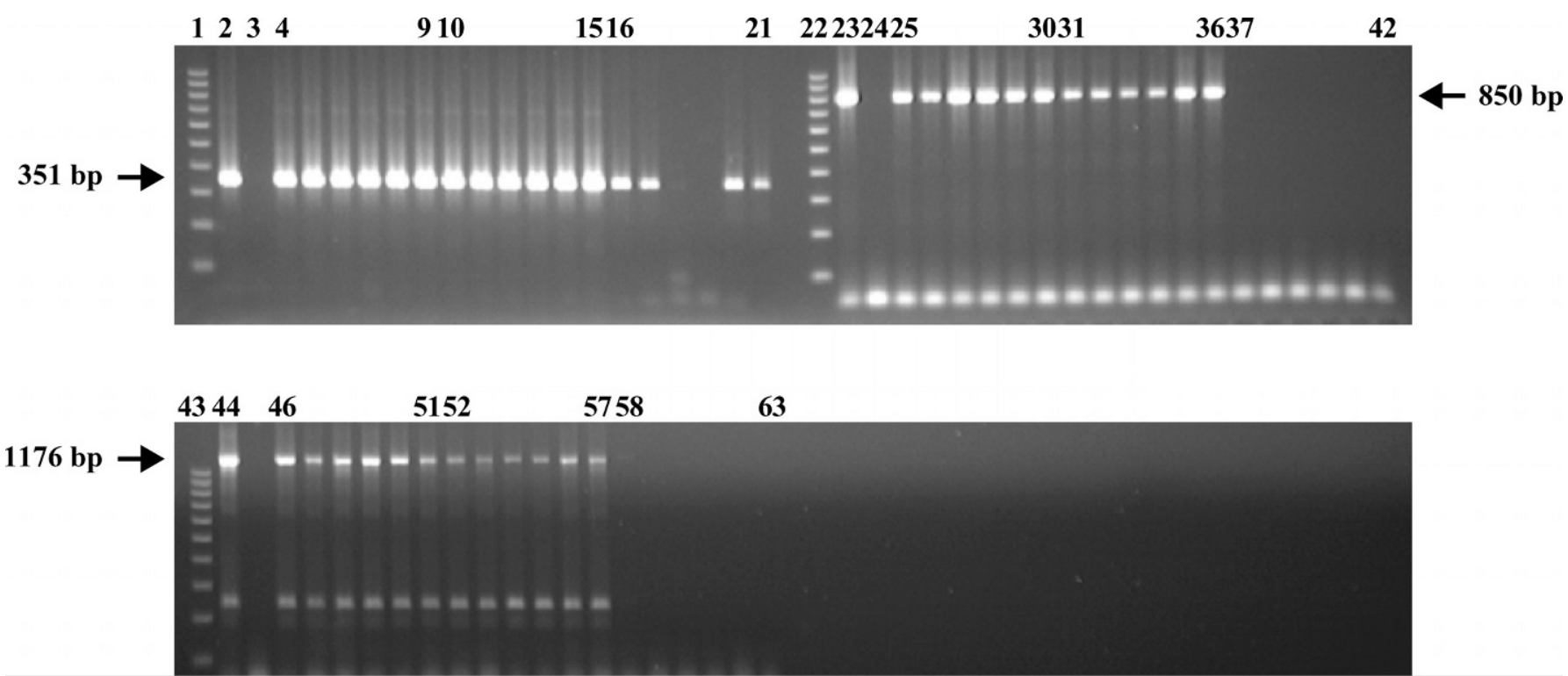

Figure 1. Detection of rubisco fragments in ruminal fluid, duodenal digesta, and feces. Lane No. 1, 22, and 43=100-bp markers (100 bp-1 kb); 2, 23, and $44=$ positive controls; 3, 24, and $45=$ negative controls. Sample DNA run as duplicates for each of 3 animals consuming non-GM diets during period 1. Lane No. 4 to 9,25 to 30, and 46 to 51 show rumen fluid DNA being amplified for the 3 rubisco sizes; 10 to 15, 31 to 37, and 52 to 57 show duodenal digesta DNA being amplified for the 3 rubisco sizes; 16 to 21,37 to 42 , and 58 to 63 show fecal DNA being amplified for each of the 3 rubisco sizes.

detected and a faint signal for the $850 \mathrm{bp}$ fragment was recorded in only 2 of the 9 samples. These fragment sizes are appreciably larger than those initially reported by Einspanier et al. (2001).

In addition to the 189-bp fragments of the rubisco gene initially detected in milk, fragments of $351 \mathrm{bp}$ and, in a limited number of cases, 850-bp fragments, were also detected (Figure 2). However, no DNA of $1176 \mathrm{bp}$ was detected in any of the milk samples examined. As suggested previously, the loss in sensitivity of the larger PCR assays may be responsible for the lack of detection of the larger DNA fragment sizes in milk. As far as the authors are aware, these data are the first attempt by any group to determine the size of plant DNA fragments of dietary origin found in milk.

Fragments of the multicopy chloroplast rubisco gene were detected in a range of samples, including milk, at larger fragment sizes than have previously been reported, whereas single-copy gene fragments, including transgenes, were not detected. Artim et al. (2001) suggested that the ability to detect fragments of plant multicopy genes is a function of their copy number, which may be as high as 10,000 compared with the single-copy of the transgenes present per cell, and analytical sensitivity. Because the presence of the rubisco gene is often taken as "proof of principle" that tDNA could be present in milk, attention is drawn to the recent publication by Klaften et al. (2003). Their study was conducted to better understand the reported detec-
$\begin{array}{llll}1 & 2 & 3 & 4\end{array}$
19

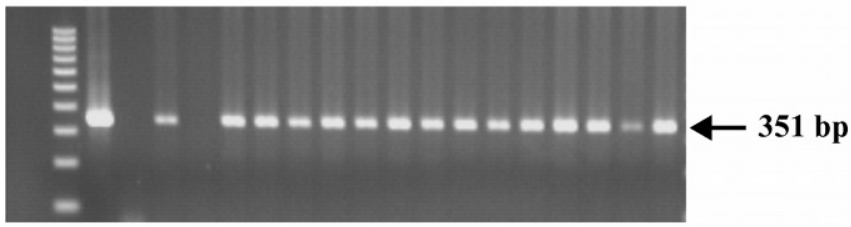

20212223

38

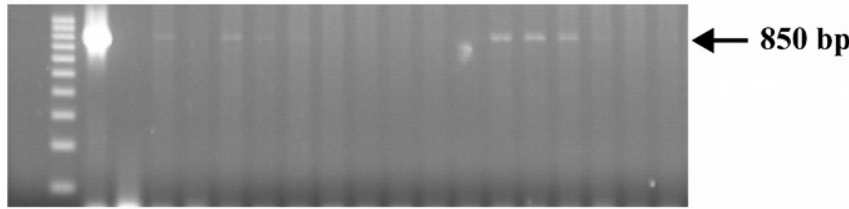

394041

57

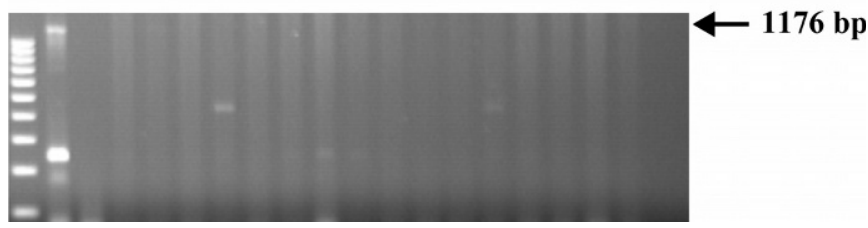

Figure 2. Detection of rubisco fragments in bovine milk. Lane No. $1,20,39=100$-bp marker ( $100 \mathrm{bp}-1 \mathrm{~kb}) ; 2,21,40$ = positive controls; $3,22,41=$ negative controls. Sample DNA in lane No. 4 to 19, 23 to 38 , and 41 to 57 are the same DNA templates extracted from milk taken from cow 6787 in period 1 , wk 4 , d 1 to 3 ; period 3 , wk 1 , d 1 to 3 ; and period 3 , wk 4 , d 1 and 2, respectively. Lane No. 4 to 19 , 23 to 38 , and 41 to 57 = detection of the 351-, 850-, and 1176-bp amplicons, respectively. 
tion of DNA fragments of multicopy plant genes in animal tissues. They noted that while under conventional PCR/Southern blotting assays, the majority of animal tissue samples showed positive signals, when further precautions were implemented, such as performing the analyses under HEPA-filter airflow, only one of 33 samples was positive. They speculated that aerosolized chloroplast DNA might be omnipresent in laboratories and difficult to avoid. Further work should be conducted in this area to clarify the issue of the presence or absence of multicopy genes in livestock products. It should be noted, however, that in the present study, no extraction control gave a positive PCR signal for $r b c L$, strongly suggesting that these signals were not generated as a result of laboratory contamination during sample preparation/analysis. In addition, sequencing confirmed that the PCR amplification of the rubisco DNA fragment in 2 milk samples was from maize.

The detection of plant DNA fragments in samples such as milk can only occur as a result of either transfer from the gastrointestinal tract into blood or as a result of contamination during sample collection. If plant DNA is absorbed, it could indicate that tDNA may also be absorbed, but if this occurs, the frequency is likely to be exceedingly low. However, if absorption does takes place, then this has been occurring through millennia and adds credence to the possibility that even if fragments of tDNA were absorbed by the animal, it would not be detrimental to health. Further work to understand such mechanisms or the likely source of contamination during sampling is recommended.

\section{CONCLUSIONS}

The current paper supports earlier work, which has shown that tDNA could not be detected in milk derived from animals receiving diets containing GM feed ingredients. The DNA in the complex feed matrix reaches and is detectable in the duodenum. The results of the current study also confirm earlier findings that DNA fragments of rubisco are found in a range of sample types, including blood and milk, and evidence is reported that the size of these fragments is larger than previously established

\section{ACKNOWLEDGMENTS}

The authors thank the U.K. Food Standards Agency for funding the project and Monsanto Co. (St. Louis, $\mathrm{MO}$ ) for providing free of charge the non-GM and GM soybean meal and ground maize and the provision of information concerning certain specific primers for the PCR analyses.

\section{REFERENCES}

Artim, L., S. Charlton, G. Dana, M. Faust, K. Glenn, G. Hartnell, P. Hunst, J. Jennings, and R. Shillito. 2001. Animal performance trials with bt crops. Biotechnology of Bacillus thuringiensis and its environmental impact. Australian National University of Canberra, S61 (Abstr.). www.animalbiotechnology.org/abstc.org

Ash, J. A., S. E. Scheideler, and C. L. Novak. 2000. The fate of genetically modified protein from Roundup Ready soybeans in the laying hen. Poult. Sci. 79(Suppl. 1):26. (Abstr.)

Boom R., C. J. A. Sol, M. M. M. Salimans, C. J. Jansen, P. M. E. Wertheim-van Dillen, and J. Van der Noordaa. 1990. Rapid and simple methods for purification of nucleic acids. J. Clin. Microbiol. 28:495-503.

Chiter, A., J. M. Forbes, and G. E. Blair. 2000. DNA stability in plant tissues: Implications for the possible transfer of genes from genetically modified food. FEBS Lett. 481:164-168.

Deaville, E. R., A. R. Moss, and D. I. Givens. 1994. The nutritional value and chemical composition of energy rich by-products for ruminants. Anim. Feed Sci. Technol. 49:261-276

Duggan, P. S., P. A. Chambers, J. Heritage, and J. M. Forbes. 2000. Survival of free DNA encoding antibiotic resistance from transgenic maize and the transformation activity of DNA in ovine saliva, ovine rumen fluid and silage effluent. FEMS Microbiol. Lett. 191:71-77.

Einspainer, R., A. Klotz, J. Kraft, K. Aulrich, R. Poser, F. Schwagele, G. Jahreis, and G. Flachowsky. 2001. The fate of forage DNA in farm animals: A collaborative case-study investigating cattle and chicken fed recombinant plant material. Eur. Food Res. Technol. 212:129-134.

Faust, M. A. 2000. Livestock products: Composition and detection of transgenic DNA and protein. Pages 1-15 in Selected Proceedings from the Agricultural Biotechnology in the Global Marketplace Symposium. Am. Soc. Anim. Sci., Savoy, IL.

James, C. 2002. Global Review of Commercialized Transgenic Crops. Publ. Int. Service for the Acquisition of Agri-Biotech Applications, Ithaca, NY.

Jennings, J. C., L. D. Albee, D. C. Kolwyck, J. B. Surber, M. L. Taylor, G. F. Hartnell, R. P. Lirette, and K. C. Glenn. 2003a. Attempts to detect transgenic and endogenous plant DNA and transgenic protein in muscle from broilers fed YieldGard Corn Borer corn. Poult. Sci. 82:371-380.

Jennings, J. C., D. C. Kolwyck, S. B. Kays, A. J. Whetsell, J. B. Surber, G. L. Cromwell, R. P. Lirette, and K. C. Glenn. 2003b. Determining whether transgenic and endogenous plant DNA and transgenic protein are detectable in muscle from swine fed Roundup Ready soybean meal. J. Anim. Sci. 81:1447-1455.

Klaften, M., A. Whetsell, J. Webster, R. Grewal, E. Fedyk, R. Einspanier, J. Jennings, R. Lirette, and K. Glenn. 2004. Animal biotechnology: Challenges and Prospects. Pages 83-99 in ACS Symposium Series 866. M. M. Bhalgat, W. P. Ridley, A. S. Felsot, and J. N. Seiber, eds. American Chemical Society, Washington, DC.

Klotz, A., and R. Einspanier. 1998. Nachweis von "novel-feed" in tier? Beeinträchtigung des verbrauchers von fleisch oder milch ist nicht zu erwarten. Mais 3:109-111.

Klotz, A., J. Meyer, and R. Einspanier. 2002. Degradation and possible carry over effects of feed DNA monitored in pigs and poultry. Eur. Food Res. Technol. 214:271-275.

MAFF. 1999. Detection of Modified Organisms in Food. MAFF Research and Development Surveillence Rep. No. 415.

Phipps, R. H., and D. E. Beever. 2001. Detection of transgenic DNA in bovine milk: Results for cows receiving a TMR containing Bt insect protected maize grain (MON810). Page 476 in Proc. Int. Anim. Agric. and Food Sci. Conf., Indianapolis, IN. (Abstr.)

Phipps, R. H., D. E. Beever, and D. J. Humphries. 2002. Detection of transgenic DNA in milk from cows receiving herbicide tolerant (CP4EPSPS) soybean meal. Livest. Prod. Sci. 73:269-273.

Reuter, T., and K. Aulrich. 2003. Investigation on genetically modified maize (Bt-maize) in pig nutrition: Fate of feed-ingested foreign DNA in pig bodies. Eur. Food Res. Technol. 216:185-192. 
Smith, N., E. R. Deaville, W. S. Hawes, and G. Whitelam. 2000. The effects of commercial-scale processing on the integrity of DNA in animal feeds. Pages 23-35 in Proc. of the 45th Nottingham Feed Manufacturers' Conf., Nottingham, U.K.

Sutton, J. D., S. B. Cammell, R. H. Phipps, D. E. Beever, and D. J. Humphries. 2000. The effect of crop maturity on the nutritional value of maize silage for lactating dairy cows. Part 2. Ruminal and post-ruminal digestion. Anim. Sci. 71:391-400.
Weber, T. E., and B. T. Richert. 2001. Grower-finisher growth performance and carcass characteristics including attempts to detect transgenic plant DNA and protein in muscle from pigs fed genetically modified "Bt" corn. J. Anim. Sci. 79 (Suppl. 2):67. (Abstr.)

Wurz, A., and R. Willmund. 1997. Identification of transgenic glyphosate-resistant soybeans. Pages 115-117 in Food Produced by Means of Genetic Engineering, 2nd status report. G. A. Schreiber, K. W. Bogl, ed. Bundesinstitut fur gesundheitlichen Verbraucherchutz and Veterinarmedizin, BgVV, Berlin, Germany. 